\title{
The long-term use of nitrogen fertiliser in intensive hill country farming
}

D. DANIELL

\author{
Wairere Romneys, R.D. 6, Masterton
}

\begin{abstract}
In 1969 the initial objective in using a nitrogen compound fertiliser was to bridge a feed deficit in late winter-early spring. Further advantages were observed, including an improvement in pastures from browntop to ryegrass dominance, better growth into dry summer, and faster recovery from droughts. Diammonium phosphate (DAP) was also incorporated into land development out of manuka, resulting in much faster establishment of dense pasture. Cost comparisons with superphosphate encouraged the use of DAP as an annual maintenance fertiliser from 1975 , usually at a rate of $125 \mathrm{~kg} / \mathrm{ha}$. Details are given of sulphur additives, molybdenum, lime and copper for animal health. The lift in productivity from 1969 to 1992 is shown. The conclusion is that a DAP/ sulphur fertiliser applied from late autumn to early spring is a cost-effective and balanced input. It allows a high stocking rate (12/ha) on poorer hill country, without supplementary feed, plus high per head performance. Feed generated has been sufficient to shear 2100 ram hoggets in early August, culminating in ram sales of 1400 per year. Lambing percentages are above $130 \%$ survival to sale in good years, and wool weights have averaged $7.7 \mathrm{~kg} /$ year, including wool sold on sheeps' back. Ewe hoggets are mated, averaging $30 \%$ survival to sale.
\end{abstract}

Keywords: diammonium phosphate, feed cover, fertiliser, hill country, land development

This story started over 30 years ago. My father, John Daniell, travelled to the UK and Europe in 1962 on a Nuffield farming scholarship. There he witnessed first hand the value of nitrogen fertiliser on pasture. A few years later John spoke to Ray Brougham and David Baker about the possible use of nitrogen fertiliser in hill country. Ray mentioned the potential for diammonium phosphate (DAP), a combination NP fertiliser.

In August 1969, a typical late-winter feed pinch persuaded John to fly DAP onto a few paddocks for weaners. The nitrogen boost helped bridge the feed deficit, but more than that, the treated pasture seemed to grow better lambs. After a summer dry spell, those same paddocks seemed to bounce back more quickly with autumn growth. Three paddocks had DAP for 5 successive years. The result was that pasture production was lifted onto a higher plane, into a ryegrass/white clover-dominant sward instead of the usual slide into browntop and other poorer species. Prior to this, the reversion of swards had seemed inevitable, taking about 7 years for pasture developed by giant discing, and only 4 years for those developed just by oversowing. DAP seemed to offer a new dimension in hill country farming.

It should be mentioned that in 1969, 1972 and 1973 the Wairarapa experienced drought seasons. The outof-season pasture growth prompted by DAP was a real bonus. Winter and early spring are the only reliable grass-growing seasons at Wairere, with moisture guaranteed. The trick is to maximise growth at those times, and provide pasture and stock a running start into the dry season beyond. Prior to the use of DAP the winter had been the major problem for feed supply. Much of the winter dormancy and slow spring were due to nitrogen deficiency. Also, observation from the first several years of application indicated that clovers seemed to be thriving under the new regime, rather than being suppressed as the armchair critics had supposed.

In 1973 I wrote down some of John's observations on the use of DAP, at the prompting of Jim White, lecturer at Lincoln College. One observation was that the soils must have other essential plant and animal nutrients. Deficiencies of animal nutrients seemed to be accentuated by the use of DAP, and John eventually took to flying copper on with the fertiliser every year. Porina and manuka beetle control is paramount; the approach of putting on enough fertiliser to allow the grass to outgrow the underground demand is inadequate in some years!

This year-round productivity boost encouraged John to consider using DAP as an annual maintenance fertiliser instead of superphosphate. An analysis showed that the reduced transport and flying costs of the high analysis product made DAP more cost efficient than super.

In 1974 he took the plunge and topdressed all the developed pasture with DAP. He was soon able to take advantage of the ripple-effect on stocking rate and nutritional levels. Weaners could be. grown at 0.3 to 0.4 $\mathrm{kg} /$ day through the late winter, allowing profitable sale 
of yearlings, and the mating of yearling heifers. The improved pasture growth allowed for the boosting of 2-year heifers with calves prior to mating, promoting a conception rate equal to that of the older cows.

Soil tests in the early 1960 s showed $\mathrm{pH}$ levels of 4.9 to 5.3, and phosphate levels of 1 to 3. The MAF recipe of molybdic super plus clover seed was inadequate to create a transformation to top-producing pasture. A liming programme, started in 1964 , seemed to turn a key, especially on the clay country.

During the 1970s much of the sandstone country on Wairere was being developed

Figure 1 Pasture composition comparison

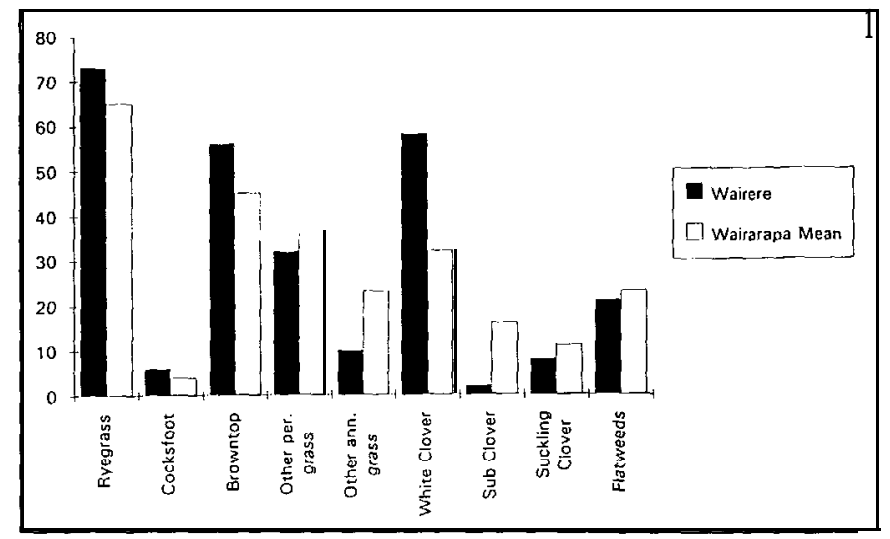
out of manuka, and some gorse, into pasture. In 1973, John decided that a big initial dose of fertiliser would be the most cost effective way to quickly develop high octane pasture. A recipe of 5 tha of lime, plus $1 / 2 \mathrm{t}$ of superphosphate equivalent in the first 18 months was tried, and proved spectacularly successful, A strategic application of $125 \mathrm{~kg} \mathrm{DAP} / \mathrm{ha}$, as part of the $1 / 2 \mathrm{t}$ phosphate, succeeded in establishing a strong ryegrass/clover sward which could compete against manuka and gorse seedlings. The concept of filling the "bucket of fertility" in one hit is one that has been increasingly adopted as a standard practice for developing low fertility soils.

In 1976, neighbouring farmer Trevor Oliver tarsealed his ridge-top airstrip and the scene was set for winter applications of nitrogen fertilisers. John evolved a system of flying DAP onto Wairere from late April through to early July, doing about a quarter of the farm at a time, usually after grazing that country hard with big mobs of ewes and cows. With a sigh of relief, the hayshed doors were closed forever.

DAP has been used as an annual maintenance

Figure 2 Wairere farm production analysis

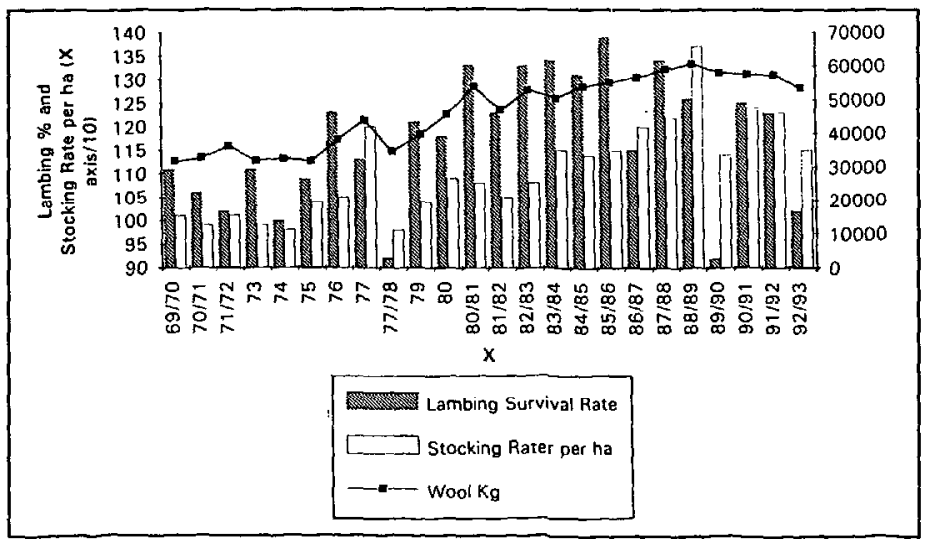

fertiliser ever since, apart from 1986 when DAP was expensive. Sulphur super was put on that autumn instead, but the late winter squeeze prompted the use of some urea in early August. Soil tests over the last 6 years show $\mathrm{pH}$ averaging 5.9, $\mathrm{P}$ level averaging 18 (always lower on the sandstone), and $\mathrm{S}$ level of 7-19.

Wairere production from 1969 to 1993 is depicted in Figure 1. During this period stock units were increased from 8600 to an average of 13000 .

Ewe hoggets have been lambed since 1966, with a range in lambing from $13 \%$ after a drought to $50 \%$ after a good season; the usual range is $\mathbf{3 0 - 3 5 \%}$.

Cows are calved late, starting mid-October. Selling policy has varied from unloading as weaners to selling 13-month bulls. Forty years of rainfall recording show an annual average of $1100 \mathrm{~mm}$, but further analysis shows that the 6-month period from November to April has an average monthly rainfall of $60 \mathrm{~mm}$. Strong winds exacerbate the moisture shortage, and encourage a flexible selling policy of surplus stock. A preChristmas unload is often a wise move, and a reduction to winter stock numbers by the end of February is sound policy for the average season.

Animal production levels seem to have plateaued if not declined slightly, though next year promises to be a winner! It would not have to be very good to improve on 1992.

Animal tissue tests show very low copper levels in cattle, but high in sheep. The policy of putting $3.25 \mathrm{~kg} /$ ha of $\mathrm{CuSO} 4$ with fertiliser annually has been discontinued in favour of injecting cattle or using boluses. Cobalt levels are not high, but above the minimum level. Selenium levels in 
sheep livers are good, though selenium is added in the minimal drenching programme.

Herbage analysis, done quarterly for 18 months by Neil McLaren in 1981-82, showed good nutrient levels, and an average N:S ratio of 12:1. Pasture composition comparisons with a Wairarapa mean, as measured by the Ravensdown nitrogen users' survey in 1991, are depicted in Figure 2.

What will be the next frontier? What productivity level can we expect on a property of 250-530 metres altitude, with $67 \%$ class VI and VII country, and only $2 \%$ flat? The shift towards meat production at the expense of wool is obvious. Higher cattle ratios are becoming favoured not just for income generation, but as a method of reducing internal parasite contamination for sheep. Perhaps the hill country farm of the future will have a deer fence around the boundary, farm deer, sheep and cattle in equal proportions, and have $20 \%$ of the land area in trees. 